\title{
Research of Experimental Teaching Method of Circuit Theory Based on "Laboratory, Simulation and Project"
}

\author{
Guangjun Yuan ${ }^{1, a}$, Jiyuan Sun ${ }^{1, b}$ and Ningning Jiang ${ }^{1, c}$ \\ ${ }^{1}$ College of Electrical and information Engineering Beihua University, Jilin Jilin 132021, China \\ aygj791223@163.com, bdick780818@163.com, 782033955@qq.com
}

Keywords: Engineering object method; Research of experimental teaching; Circuit theory; Innovation

\begin{abstract}
The experimental teaching is an important part of the teaching system in colleges and universities. In order to change the status that only pay attention to theory and scientific, but lack of experiment and practice, it is imperative to carry out the reform of experiment teaching, such as the experiment management mode, the experimental teaching system, experimental teaching method, and experiment content each other. To cultivate students' comprehensive ability and practical ability to be fully considered, most important of all, students should be the main part in the teaching activity. The reform experience laid a foundation for us to train high quality persons with originality and practical ability.
\end{abstract}

\section{Introduction}

Chinese education put forward from 2010 the "national long-term education reform and development plan", 2012 eighteen to 2013 the third Plenary Session of the 18th CPC Central Committee report, "the CPC Central Committee on deepening reform of the overall number of major issues", to 2015 the fifth Plenary Session of the 18th CPC Central Committee the "CPC Central Committee on the thirteenth five year plan for national economic and social development of the proposal", these files all stressed to cultivate students' sense of social responsibility, innovation spirit and practice ability [1]. The quality of personnel training, should not only look at the students' test scores, but also pay more attention to seeing whether the students have the nation and people's sense of social responsibility, the courage to explore the spirit of innovation and ability to solve the problem of practical ability. The circuit theory experiment is an important support of theory and practice, through experiment and practice, students can integrate theory with practice better and better, repair the gap between courses [2]. Therefore, colleges and universities must attach importance to experimental teaching research, reform in education of experiment, and make the teaching quality can fully meet the needs of the rapid development of society.

\section{Circuit Experiment Teaching Reform}

Aiming at series of problems, such as the deficiency of the constitution, monotonous teaching content [3] and single examination mode [4], it needs to find the solutions to them. Then, the reform model refers with Fig. 1. 


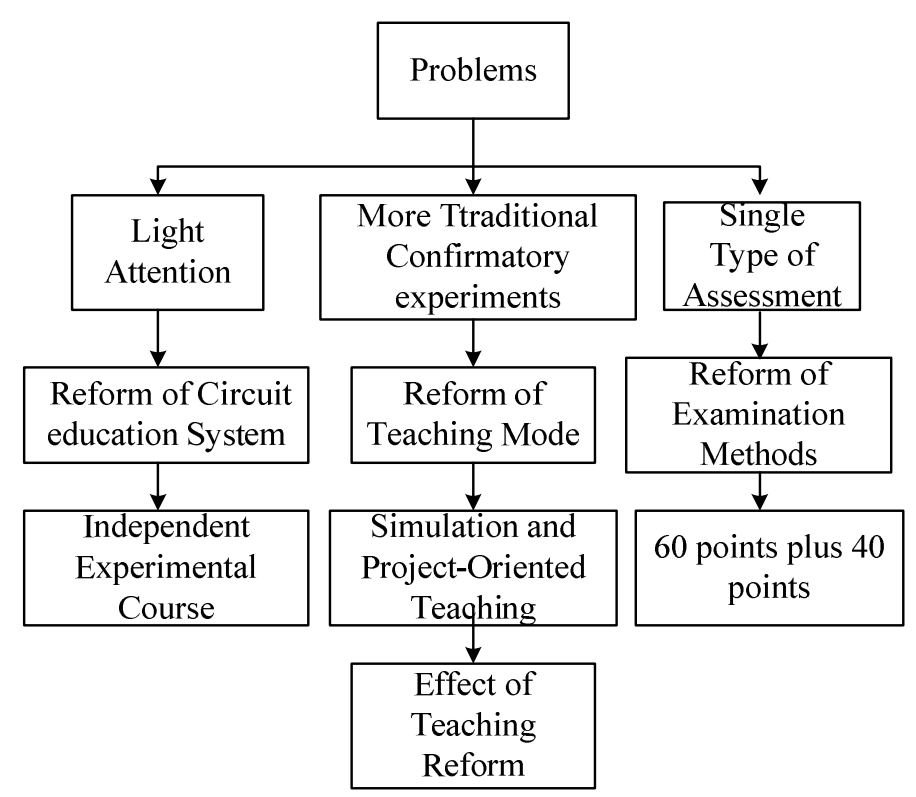

Figure 1. Construction of reform model

Reform of the Teaching Mode of Circuit Experiment. Multisim12.0 provides a virtual electronic workbench with a variety of testing instruments, a variety of components, it is easy for students to verify, understand and use the content of the theory without the limitation of the setting of Laboratory [5-6]. For example, before doing the confirmatory experiment of "power equivalent transformation", students can draw the circuit diagram by the soft Multisim12.0, as shown in Fig. 2. Simulations results are provided to verify the correctness and the feasibility of this method are presented. For the external circuit, the actual voltage source is equivalent to the actual current source, the same load 200 $\Omega$ in the actual current source and the actual voltage source to obtain the same size of power $3.472 \mathrm{~mW}$, as shown in Fig. 2.

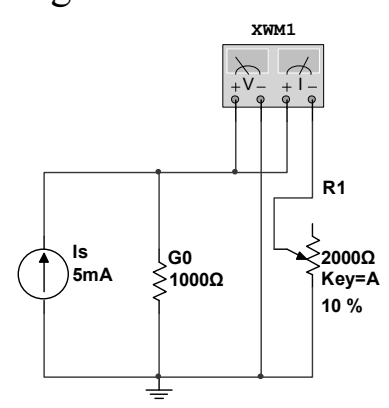

(a)

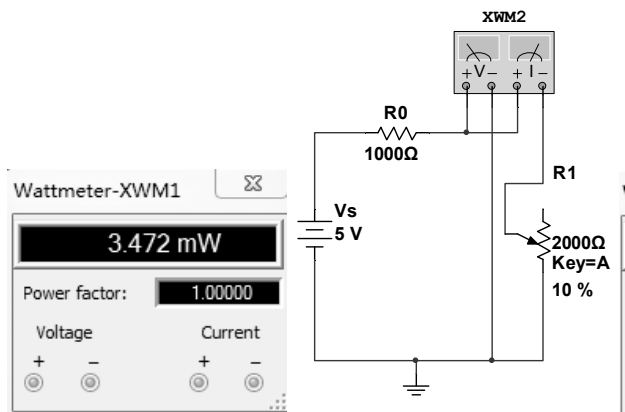

(b) (c)

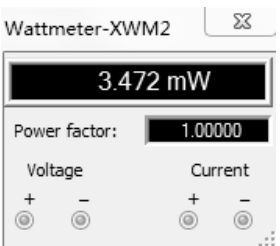

(d)

Figure 2. Simulation circuit of actual voltage source and current source

It can guide students to think further in the experiment under what conditions, the load can achieve maximum power. When the load $\mathrm{R}_{1}$ is adjusted to $1000 \Omega$ (coefficient of $50 \%$ ), the power is $6.250 \mathrm{~mW}$, which is the maximum power transfer theorem. Multisim12.0 has the advantages of simple operation, easy to use etc, it used to debug the virtual circuit, students can have a comprehensive understanding of relevant knowledge in a very short period of time, and it also can stimulate the students' interest in the course "circuit theory", and improve their ability to innovate, and to improve the quality of teaching theory also plays a very good supporting effect.The students strengthen the experiment preparation by Multisim12.0 simulation software, so that they can be well prepared for each experiment at all, the results have been significantly improved than before. 
Comprehensive Design Experiment based on Engineering Object Method. The verification experiment aims to strengthen the training of students' basic experimental skills. Students who have the ability to explore their potential through the development of integrated design experiments to further develop their ability to analyze and solve problems independently.In order to obtain more growth opportunities, the assessment of outstanding students can enter college innovation center, divided by interest groups to participate in Undergraduate Electronic Design Contest, innovation and entrepreneurship competitions under the guidance of scientific research assistants and teachers [7].The teaching method of engineering object is a kind of innovative engineering teaching method based on working process [8-9].The introduction of engineering object circuit experiment teaching, the teacher can speak while doing, students can do in learning and doing, make students understand and master knowledge and skills more systematically and comprehensively.The rich and the actual object type may cause the student to have the keen interest to the circuit curriculum [10].Circuit experiment will rewrite the previous experimental report into the project application, the experimental process is to achieve the project, and the experimental report is an end of project summary report. The flow chart of the project object method is shown in Fig. 3.

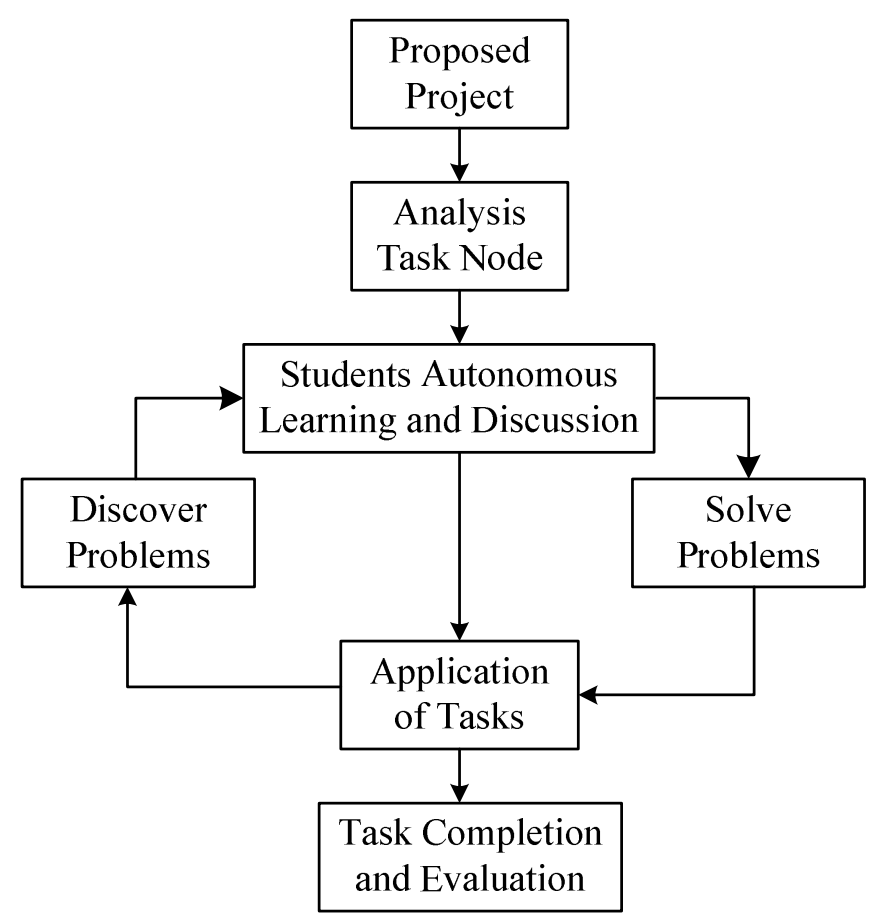

Figure 3. Flow chart of engineering object method

Circuit Experiment Teaching Reform of Examination Method. The single examination method can not reflect the situation of students' experimental skills fairly and objectively. In order to avoid this situation, we have carried out the reform of the examination methods. The assessment method is to take the form of "the usual performance + the end of the sample test", and the additional experiment is carried out in the form of project defense, which deepens the understanding of the theoretical knowledge, and makes the students' thinking ability get exercise. 
Table 1 Evaluation methods of experimental results

\begin{tabular}{|c|c|c|}
\hline Total project & Sub project & Requirement \\
\hline \multirow[t]{4}{*}{$\begin{array}{l}\text { Peacetime } \\
\text { achievements } \\
(60 \%) \\
\end{array}$} & $\begin{array}{l}\text { attendence } \\
(5 \%)\end{array}$ & In each experiment, full attendence \\
\hline & $\begin{array}{l}\text { Preview } \\
(15 \%)\end{array}$ & $\begin{array}{l}\text { Familiar with the content of the } \\
\text { experiment, and hold Multisim } 12.0 \\
\text { simulation circuit and simulation results }\end{array}$ \\
\hline & $\begin{array}{l}\text { Practical operation } \\
(30 \%)\end{array}$ & $\begin{array}{l}\text { Circuit connection specification, analyze } \\
\text { and solve problems, innovate }\end{array}$ \\
\hline & $\begin{array}{l}\text { Experimental report } \\
\qquad(10 \%)\end{array}$ & $\begin{array}{l}\text { The report is written neatly, the chart, the } \\
\text { table, the data, the error analysis is } \\
\text { correct, the content is complete, the } \\
\text { experimental result is true }\end{array}$ \\
\hline \multirow[t]{2}{*}{$\begin{array}{l}\text { Final exam } \\
(40 \%)\end{array}$} & $\begin{array}{l}\text { Required experiment } \\
\qquad(40 \%)\end{array}$ & $\begin{array}{l}10 \text { sets of difficult degree of paper, the } \\
\text { students draw a choice, in the specified } \\
\text { time to connect and answer. Roll out of } 50 \\
\text { points, and finally converted to the final } \\
\text { assessment results }\end{array}$ \\
\hline & Additional experiment & $\begin{array}{l}\text { Take the form of project defense. } \\
\text { Students have the right to choose not to do } \\
\text { this, for the students with good answers } \\
\text { should be given a different program } \\
\text { points, and was recommended to join the } \\
\text { innovation team }\end{array}$ \\
\hline
\end{tabular}

\section{Effect of Experimental Teaching Reform}

According to the state of higher engineering education curriculum teaching the basic requirements, meet the requirements of the teaching program, based on the existing experimental equipment, electrical and Information Engineering Beihua University purchased MEEL-11 high performance electrical technology experimental equipment. Director of the laboratory of experimental teachers and the author have jointly compiled a corresponding materials "circuit experiment course", based on experiment, increase the design and comprehensive experiments and additional experiments, for the students, who have specialized knowledge of a subject and be energy to spare, provided a good platform[11]. At the same time, "circuit theory" course was awarded the provincial excellent course. Excellent students, entered the innovation team, participated in the application of innovation and entrepreneurship projects. They successfully applied to a number of national projects.In the National Undergraduate Electronic Design and Challenge Cup competition, won the national two prizes and provincial first prize, effectively improve the students' innovation consciousness and ability.

\section{Summary}

"Circuit theory" is an important part of the training of basic skills in practice teaching, through the practice of curriculum construction in recent years, the circuit course group of electrical and information engineering of Beihua University has made some attempt to reform the experimental teaching system, experimental teaching mode and experiment mode of teaching evaluation, and achieved good results, and promote the students' theory and practice, improve the students' learning initiative and enthusiasm, improve the students' awareness of teamwork. 
With the deepening of the reform of higher education experimental curriculum in our country, the experimental teaching is bound to go out of the traditional mode, and to the development of diversity and details.

\section{Acknowledgements}

Research Project of Education and Teaching Reform in Beihua University: "Lab + Network + Classroom" Diversified Research on Teaching Method of Circuit Experiment (number: XJQN2016003)

\section{References}

[1] Y. F. Yang: Focusing on cultivating students' sense of social responsibility, innovative spirit and practical ability, improve the quality of education of China Education newspaper, 2016-3-2 (5). (In Chinese)

[2] H.S. Zhong: The significance of experiment in circuit theory teaching of Journal of Wuhan University experiment in circuit theory teaching (SCIENCE EDITION), Vol.58 (2012), No. s2, p. 194- 196. (In Chinese)

[3] F.G. Meng: Reform of Teaching Mode and Method of "Circuit Principle Experiment" of Laboratory Research and Exploration, Vol.28 (2009), No.3, p. 236- 238.(in Chinese)

[4] Y. Xie, Y.E. Liao: Exploration on the Teaching Reform of "Circuit" Course of China Electric Power Education, (2014), No.8, p. 71- 72. (In Chinese)

[5] J. Hao, X. Liu The Reform of "Circuit" Experiment Teaching under the Goal of "One Real and Two Creation" of Science and Technology Innovation and Application, Vol. 34 (2012), p.301. (In Chinese)

[6]. X.F. Qi: Application of Multisim12.0 in the teaching of electrical and electronic technology, (2016), No.1, p. 22- 23(in Chinese)

[7] S.L. Liu, L. Qin: Experimental Teaching Reform and Practice of "Circuit" of China Electric Power Education, Vol. 36 (2014), p.170-171. (In Chinese)

[8] J.Y. Sun. and G.J. Yuan: Engineering Object Teaching Method to Cultivate the Innovation Ability of Experimental Technology and Management, Vol. 31 (2014) No.2, p.21-22. (In Chinese)

[9] G.J. Yuan , J.Y. Sun and Bai Jing: Research of Microcomputer Principle Course of Engineering Object Method in the Teaching Practice of the Computer Education, (2016) No.4, p. 127-128, 132.(In Chinese)

[10] Z .Chen, D.s. Zou: The Design of Electronic Technology Innovation (Science Press, China 2008). (In Chinese)

[11] W.M. Qin, T. Lu and G.J. Yuan: Circuit Experiment Tutorial (Jilin University press, China 2015). (In Chinese) 